DOI https://doi.org/10.30525/978-9934-588-92-1-19

\title{
ВПЛИВ ДУХОВНОСТІ НА ПРАВО (НА ПРИКЛАДІ КОНСТИТУЦИЙНОГО ПРАВА)
}

\author{
Гордіюк С. А. \\ аспірант \\ Харківського національного університету імені В. Н. Каразіна \\ м. Харків, Украӥна
}

Теза про те, що право загалом і конституційне право зокрема володіє духовною природою, не $є$ новою і по суті ніким не піддається сумніву. Так само аксіоматичним $\epsilon$ те, що право $\epsilon$ важливим регулятором тих відносин, що існують у духовній сфері суспільства, хоча серед конституційно-правових засад суспільного ладу цій сфері приділяється найменше уваги [1, с. 360], а відповідні засади закріплюються в найбільш загальній формі [2, с. 264].

Тривалий час поняттю духовності й духовного життя надавалося релігійне звучання, як противага світськості. Не дарма перші акти конституційного характеру, наприклад, Велика хартія вольностей (1215 р.) чи Декларація прав людини і громадянина (1789 р.) у преамбулі неодмінно містили посилання на Бога як на першоджерело своєї легітимності. Втім у Новий час позначилося розмежування між духовністю і релігійністю, тож уже конституції «першого покоління» жодних посилань на своє божественне начало не містили; немає таких посилань і в переважній більшості сучасних конституцій (чинна Конституція України є винятком із загального правила).

У сучасній науковій (філософській, соціологічній, педагогічній) літературі духовність постає як «інтегральна категорія, що виражає теоретико-пізнавальну, художньо-творчу та морально-аксіологічну активність людини» [3], «визначає смисложиттєві цінності, які формують людяне відношення до інших, гуманізм, забезпечують духовний розвиток особистості» [4, с. 7]. При цьому духовний світ і духовне життя людини тлумачаться широко, охоплюючи все, що пов'язано з внутрішнім психічним життям людини, іiі моральним світом, з певною сукупністю ідей, поглядів, прагнень тощо. У такому контексті релігійний аспект духовності розглядається лише як один 3 елементів внутрішнього світу людини, поряд із духовністю світською.

Як зазначав М. Бердяєв, будь-яка культура (навіть матеріальна) $є$ культурою духа, має духовну основу, $є$ продуктом творчої роботи духа 
над природними стихіями. Виражаючи свої думки, почуття, ідеали, вірування, людина фіксує їх у творах літератури і мистецтва, науки i релігії. Збереженню і передачі їх наступним поколінням слугують освіта і традиції. Усе це й складає духовну сферу суспільного життя. У даному контексті й юридична конституція (як у формальному, так і в матеріальному сенсі слова) $є$ «матеріальним відбитком» відповідних духовних явищ і процесів.

Звертаючись до духовних засад права, ми, тим не менш, відзначаємо, що в першу чергу воно є матеріальним. У тому чи іншому місці, у той чи інший час право було, є і буде передусім об'єктивною реальністю, «буквою» закону - тим, що в європейській правовій традиції з давньоримських часів прийнято називати corpus iuris. I конституційне право не є винятком.

Хоча право і духовність часто розглядаються як протиборствуючі сили, вони глибоко пов'язані. Духовність може підштовхнути правові системи до змін. Справді, історія засвідчує, що правові системи розвиваються через «одухотворення» різними способами. Зокрема, духовність може сприяти дематеріалізації правових систем; заохочувати обмеження свавілля й диктату як центральну рису права; сприяти скороченню примусу як основного засобу реалізації права; стимулювати примат спілкування як юридичну мету; заохочувати більш тісну правову взаємодію між людьми і природним довкіллям; підвищити повагу до права. Розглянемо ці напрямки впливу духовності на право на прикладі конституційного права як провідної галузі.

По-перше, духовність може сприяти дематеріалізації правових систем, що означає зменшення залежності правової системи від матеріальних елементів, таких як юридичні документи, заради максимальної ефективності. Дематеріалізація відбувається, наприклад, коли намір переважає над буквальним тлумаченням політичних угод i зафіксованих у законодавстві правил; коли правові системи скорочують зайвий формалізм; коли право стимулює представництво і створення певних суспільних інституцій.

Як засвідчує історичний досвід, чим менш матеріально залежною $є$ правова система, тим більш духовною вона є. Класичним прикладом конституційно-правової дематеріалізації $\epsilon$ неписана британська конституція. На відміну від переважної більшості сучасних демократичних держав, Сполучене Королівство має конституцію тільки абстрактно - так би мовити, в духовному (матеріально-юридичному) сенсі, й складається з багатьох історично важливих актів і принципів, статутного права, парламентських звичаїв, прецедентів і навіть праць найбільш авторитетних науковців. Втім духовна цілісність i 
довершеність змісту британської конституції вже протягом кількох століть слугують запорукою стабільності конституційного ладу та його сталого прогресивного розвитку. На противагу британському досвіду, чинна Конституція України, що розроблялася рекордно довго, оскільки iii розробники намагалися зафіксувати максимально широке коло вузлових питань суспільного й державного життя, але приймалася за відсутності духовної єдності Українського народу, тепер піддається регулярному перегляду, незважаючи на свій писаний характер i складний порядок внесення змін.

По-друге, духовність у зворотній пропорції співвідноситься 3 опорою політико-правової системи на панування як визначальний фактор відповідних суспільних відносин. Іншими словами, чим більшим є панування, дозволене чи здійснюване політико-правовою системою, тим нижчою $є$ міра конституційно-правового одухотворення. Панування є протилежним духовності, воно спирається на нерівність, силу й підпорядкування, натомість духовність грунтується на повазі, спілкуванні й свободі. У цьому контексті духовність є однією 3 підвалин конституціоналізму як теорії та практики розбудови обмеженого врядування. Якщо конституційно-правова система створюється передусім для обмеження приватного й публічного панування, то й розвивається вона тільки тоді, коли поступово переходить від такого панування до правового етосу рівноправного спілкування.

По-третє, духовність і конституційне право взаємодіють шляхом скорочення правового примусу. Звісно, легальний примус - необхідна умова існування будь-якої політико-правової системи; на думку багатьох філософів і теоретиків права, примусовість (загальнообов'язковість) є однією з характеристик, що відрізняє право від інших соціальних регуляторів. Однак, оскільки примус обмежує свободу, духовність сприяє скороченню правового примусу до необхідного мінімального рівня. Прикладів в історії конституційного права цілком достатньо. Наприклад, важливим досягненням одухотворення було виключення тортур з правової системи, в тому числі шляхом закріплення на рівні конституції права на особисту недоторканність. При цьому варто відзначити, що тортури, санкціоновані судом, зникли в Англії приблизно в 1640 році, у Німеччині вони були скасовані в 1776 році, а у Франції тривали до 1789 року [6, с. 2]: в усіх випадках скасування тортур відбувалося на тлі формування конституційного ладу.

По-четверте, духовність також впливає на еволюцію форм політичного режиму, передусім із точки зору тих способів, якими право пов'язує людей. Менш духовні правові системи формують 86 
громадянське суспільство на основі прав, які взаємно поважаються i забезпечуються в судовому порядку. Але це компактно проживаюча спільнота, а не справжнє співтовариство. Натомість в основі духовності лежить єднання зі всесвітом, людством і, врешті-решт, із Богом. Відтак духовно розвинені правові системи, таким чином, стимулюють i неформальне спілкування між людьми, поза за межами умовної множини соціальних інститутів, груп, юридичних прав та обов'язків. У даному контексті варто навести приклад держав арабського Сходу, чиї конституції закріплюють принцип єдності арабської нації, скріпленої єдністю мусульманської віри. Та й Основний закон ФРН вживає термін «німець» більше в духовному, ніж формальноюридичному сенсі. Загалом, створення Європейського Союзу - гарний приклад не тільки організаційно-правового, але й духовного єднання.

По-п'яте, правова духовність надихає на спілкування не тільки 3 іншими людьми, але й з усіма живими істотами та навколишнім середовищем. Як наслідок, питання екології дедалі більше долучаються до сфери конституційно-правового регулювання. Найбільш яскравий приклад такого роду - Хартія навколишнього середовища (2004 р.), що стала невід’ємною складовою чинної Конституції Франції. Духовність допомагає людям подолати традиційний ієрархічний, зверхній підхід до природи, і розглядати тих чи інших представників флори і фауни як цінність, а не як об'єкт для експлуатації.

Нарешті, духовність також допомагає розвивати повагу до правових систем як важливих інструментів розвитку людини. Повага необхідний відправний пункт справжнього спілкування. В іншому разі одержаний союз буде характеризуватися пануванням, а не паритетним спілкуванням, не кажучи вже про духовну єдність. Коли люди розглядають правову систему i правовий вимір як частину інструментарію для забезпечення більш високого рівня духовної єдності, їм легше налагодити конструктивний діалог та ефективну взаємодію між собою, ніж коли вони розглядають правові явища як звичайний продукт тимчасової угоди між людьми. Чим глибшою $\epsilon$ причина прояву поваги, тим легше люди цю повагу виявляють, тим міцнішим є суспільство.

\section{Література:}

1. Сравнительное конституционное право / ред. кол.: А.И. Ковлер, В.Е. Чиркин (отв. ред.), Ю.А. Юдин. Москва: Манускрипт, 1996. 730 с.

2. Конституция в XXI веке: сравнительно-правовое исследование / отв. ред. В.Е. Чиркин. Москва: НОРМА-ИНФРА-М, $2011.656 \mathrm{c}$. 
3. Хамітов Н.В. Духовність. Енциклопедія сучасної України. URL: http://esu.com.ua/ search_articles.php?id=19642

4. Лавриченко Н. Категорії «соціальність», «духовність» i «моральність» в сучасній педагогічній науці. Шлях освіти. № 1. C. $7-11$.

5. Нерсесянц В.С. Юриспруденция. Введение в курс общей теории права и государства. Москва: Норма, Инфра-М, 1998. 288 с.

6. Domingo R. Spiritual Influences on the Law. The Canopy Forum, Atlanta, 8 October 2019. URL: https://www.academia.edu/40836171/ Spiritual_Influences_on_the_Law

DOI https://doi.org/10.30525/978-9934-588-92-1-20

\title{
МОДЕЛІ НАГЛЯДУ ЗА ОРГАНАМИ МІСЦЕВОГО САМОВРЯДУВАННЯ У ДЕРЖАВАХ-ЧЛЕНАХ ЄВРОПЕЙСЬКОГО СОЮЗУ
}

\author{
Гришко Л. М. \\ кандидат юридичних наук, старший науковий співробітник \\ Науково-дослідного інституту державного будівництва \\ та місиевого самоврядування \\ Національної академії правових наук України \\ м. Харків, Украӥна
}

Зарубіжний досвід впровадження положень Європейської хартії місцевого самоврядування 1985 р. щодо нагляду за органами місцевого самоврядування представляє значний інтерес для України. Відповідно до положень ст. 8 Свропейської хартії місцевого самоврядування 1985 р., нагляд може здійснюватися лише відповідно до процедур та у випадках, передбачених конституцією або законами, 3 додержанням принципу пропорційності, обмежуючись питанням законності дій, а не їх доцільності. Нагляд за доцільністю допускається лише щодо делегованих повноважень [1].

Контроль/нагляд за діяльністю органів місцевого самоврядування в теорії конституційного права розрізняють за різними критеріями. За часом проведення виокремлюють попередній, поточний, остаточний $[2,60]$. Саме цей критерій класифікації беруть до уваги при характеристиці моделей нагляду за органами місцевого самоврядування. 